\title{
Exchange Rate Volatility and Aggregate Bilateral Exports of Pakistan: An Empirical Analysis
}

\author{
Saad Uddin Khan ${ }^{*}$ \\ P.Hd Student, Department of Economics, University of Karachi, Pakistan
}

DOI: $10.36348 / \mathrm{sb} .2019 . v 05 i 11.012$

| Received: 03.11.2019 | Accepted: 11.11.2019 | Published: 25.12.2019

*Corresponding author: Saad Uddin Khan

\section{Abstract}

Generalise gravity model used to evaluate the effect of exchange rate volatility and exchange rate regime on bilateral exports of Pakistan. A bilateral data set of major exports partners the USA, UK, UAE, Hong Kong and Germany for period 1982 to 2015 used in a panel framework. ARCH, GARCH, moving average standard deviation methods used for measuring volatility in bilateral exchange rate. The results found conclude that economics size (GDPJ/GDPPAK) has a significant positive effect. Distance (DIS) and relative prices (RP) are significant negative effects; exchange rate volatility and free-floating exchange rate regime have a significant positive effect on aggregate bilateral exports of major trading partners of Pakistan.

Keywords: Aggregate Exports, Exchange Rate, Volatility, Exchange Rate Regime, ARCH, GARCH and Gravity Model. Copyright @ 2019: This is an open-access article distributed under the terms of the Creative Commons Attribution license which permits unrestricted use, distribution, and reproduction in any medium for non-commercial use (NonCommercial, or CC-BY-NC) provided the original author and source are credited.

\section{INTRODUCTION ${ }^{1}$}

Export earnings play an important role in the economic stability of a country. It helps to generate excess foreign reserves and strengthen industrial growth. Therefore, every country opts all opportunities to enhance their exports earnings. Thus, it is important to analyse export determinants and its performance that depends on income of importing country (demand determinants), supply capacity of exporting country (supply determinants), relative prices of exports goods, bilateral exchange rate volatility and other controlled variables. This study focuses on exchange rate volatility and exchange rate regimes that are important determinant of exports. The volatility of the exchange rate has affected internal trade by generating uncertainty in the minds of exporters regarding earnings from international transactions as a result of which it limits international capital flow, increased prices (by applying risk premium) or, in other words, instability or ambiguity in the size of export exchange rate controls. Therefore analyzing fluctuations in exchange rate and its effect on exports is important for country like Pakistan whose economy largely depended on trade.

\footnotetext{
1 This research paper is the part of my M. Phil thesis submitted to the Higher Education Commission (HEC), Islamabad, Pakistan.
}

Pakistan exports mainly comprised of primary commodity and low tech manufactured goods. Major exports of Pakistan are cotton, knitwear, bed wear, carpets, rugs, rice, leather, fish, sports goods, fruits and vegetables. The natural exporting partners of Pakistan are India, China, Afghanistan and Iran. The traditional trading partners are United States, United Arab Emirates, United Kingdom and Germany.

An exchange rate (ER) has played a critical role in the trade performance of Pakistan on several occasions. For nearly thirty-five years, Pakistan has maintained a fixed peg regime for its ER. After 1980, Pakistan slowly and gradually amends exchange rate policy from a fixed exchange rate regime to floating (free-floating) exchange rate regime. The nuclear test conduct by Pakistan on 28 May 1998 put Pakistan economy in foreign exchange crisis. To overcome the foreign exchange crises, i.e. to stabilize the exchange rate, State Bank of Pakistan adopts feasible policy for exchange rate system. A multiple exchange rate system introduced to overcome the crisis faced by Pakistan economy, involving official, interbank, and a combined exchange rate. Bank permitted to quote there exchanging rate for currencies other than the dollar. After gone through with initial period of economic 
crisis, ER reclassified on December 1998 from fixed (peg) to managed floating mechanism without any preannounced course for amending exchange rate.

The objective of the study is to investigate the effect of bilateral exchange rate volatility and freefloating exchange rate regime on aggregate exports of Pakistan for the period 1982 to 2015 in panel data framework. The current study is different in many ways. First: this study employed a generalised gravity model that explains the demand and supply side simultaneously which is much appropriate than the previous technique in Pakistani context and results obtained help to increase robustness. Second: this study measures exchange rate volatility by using bilateral exchange rate data. Third: it also explains the effect of exchange rate volatility at aggregate level. Fourth: this study uses different approaches to measure volatility to incorporate the robustness in result. Fifth: the freefloating exchange-rate regime included as a determinant of exports function that helps to measure the regime affect separately.

\section{REVIEW OF LITERATURE Theoretical Review of Literature}

After the fall of the Breton Wood system in 1973, a floating exchange rate system introduced, which started a debate on the influence of uncertainty in exchange rate (ER) on global trade. Theoretical analyses of affiliation between volatility in ER and global trade have conducted by Hooper and Kohlhagen [1], Either [2] and several other researchers. The interesting thing found in the theoretical literature is that there is no consent among researcher on the impact of uncertainty in ER and trade. Either [2], Cushman [3, 4] and Peree and Steiner [5] with the help of traditional trade theories analysed that raise in ER volatility gave adverse effects on the international trade volume. In other words, uncertainty in ER is a kind of threat or fear of loss; which creates uncertainty in mind of traders and if traders or exporters are risk-averse then they tend to reduce export [6]. Contrary to above studies, Franke [7], Viaene and De Vries [8] and Valhalla [9] demonstrated that increased in volatility in ER could affect positively on international trade volume. Herwart [10] suggested; "there might be a condition where uncertainty of exchange rates can have either positive or negative effects on trade quantity".

De Grauwe [11] explained the dominance of income effects over substitution effects could lead to a positive relationship between trade and exchange rate volatility. On behalf of importer (producer) De Grauwe [11] suggested that if producer is risk-averse so they would produce less for export due to greater uncertainty in exchange rate reduces the expected marginal revenue of export. If the producers were risk-taker, he would increase production for exports to nullify decline in export revenue.
Similarly, Demers [12] showed that assumption of risk aversion had not required for adverse effect on international trade. This study assumed that risk neutrality for a competitive firm and uncertainty in demand of goods export is due to price uncertainty which has driven from exchange rate risk. Hysteresis theoretical model on international trade concluded that increased uncertainty in ER could persuade or influence the volume of international trade, only if international transactions carry a sunk cost.

From the above discussion, we can make the following conclusion. First: high degree of uncertainty in ER lead to enhancing cost for risk-averse traders; because the rate at which the transaction takes place agreed at a time of contract, but reimbursement will made after complete delivery of export goods, this situation creates ambiguity about profits to be made from international transaction. Second: The unexpected fluctuation in ER-associated with a completely flexible ER regime could enforce government to upright trade barriers to remove the instability in economy cause reduction in trade [13]. Third: increase in volatility in the ER would increase in volume of international trade. As trade considered as opportunity by firm similar to stock, i.e. rise in volatility in ER raise the value of trade [7] it could simply understand through the concept of high risk refers to high returns.

The main cause of volatility in the exchange rate is hedging. Many theoretical studies found discussing hedging of the exchange rate that is possible in a developed country but generally not possible in case of underdeveloped and low developed countries 'due to inaccessibility of the forward markets to many traders. Even if it was possible, they ought to face cost limitation [14]. Although most economists believe that price of any commodity could determined by demand and supply force present in market. Therefore, value of one currency in terms of another currency can be determined but offers a dilemma of prevarication among two countries. In other words, every variation in ER creates uncertainty, which could show on international trade volume. If changes in ER become surprising, this creates ambiguity on profits to make from an international transaction, or we can say reduced, the benefit from trade. It is difficult to estimate the time interval of the international transaction in most cases because of the length of contract is generally large in comparison to the maturity period that is quite low.

The conclusion from the above discussion reveals that theoretical considerations remove queries to support for the unadventurous supposition that volatility in ER has a negative impact on the international trade; more conceptual support required to support the unadventurous supposition. In other words, no consensuses among researchers were found based on theoretical concepts. 


\section{Empirical Review of Literature}

In literature, most studies found using bilateral data set are in context of developed countries. Akhter and Hilton [15] initiated the effect of ER volatility on bilateral trade flow using tradition trade model. They examined trade between West Germany and United States. They found that volatility in ER has adverse significant impact on the bilateral trade between two countries. Volatility in ER measured through standard deviation approach by using real effective ER. This result rejected by Gotur [16]. He found insignificant impact of volatility in ER on volume of trade. The data set contains three more countries (i.e. France, Japan \& United Kingdom) in Akhter and Hilton [15] study and extended the study period. Aristotelous [17] used a gravity model to explain effect of ER volatility on bilateral trade between the United States of America and United Kingdom using more than hundred-year annual data with exchange rate regime affect capturing separately. The result found to be insignificant effect of volatility in ER and ER regime has positive significant effect on bilateral exports between UK and US.

Some argument found in the literature are; First: "floating exchange rate may or may not be volatile depending on how much it changes over time since the floating exchange rate is free to change and generally expected to be more volatile" [18]. Second: a fixed exchange rate theoretical do not amend as per characterisation i.e. have no variation. Nevertheless, fixed ER frequently revalued (devalued), implying that it can change over time and maybe volatile. Therefore, volatility in ER refers to degree of prices of currencies, which tend to fluctuate eventually. The measure captures the uncertainty due to unpredictable fluctuation in the ER. Thus, volatility in ER had characterised as sudden unexpected amendment in ER. The importance of utilising different exchange rates reported by Cushman [4]. Nominal exchange rate, real exchange rate and real effective exchange rate frequently used in literature. The nominal exchange rate used by Akther and Hilton et al., [15], Peree et al., [5] and B. Smaghi [19]. They found significant negative effect on trade volume. McKenzie and Brooks [20] and McKenzie [21] show significant positive effect on disaggregate export while Gotur [16], Bailey, Tavlas and Ulan [22] found insignificant effect on trade volume. The real exchange rate used by Brada and Mendez [13], Asseery et al., [23], Kasman and Kasman [24] found positive significant effect. Vergil [25], Arize et al., [26], Caporal and Dorodian [27], AC Arize [28] found negative significant effect and Aristotelous [17] and Hwang Lee [29] reported insignificant effect on volume of trade. In short, no consensus found among researcher in literature by the use of different exchange rate.

Now review turn to the use of a different technique to measure exchange rate volatility.
McKenzie [30] verified different methods might outlay different results and conclusion. Normally standard deviation was an employee as tool for calculating the volatility in the exchange rate. Hooper and Kohlhagen [1] used complex method for measuring the volatility in exchange rate by using bilateral, previous and spot exchange rate. Cushman [4] amended Hooper and Kohlhagen method of measuring the uncertainty by involving third party effect. Kumar and Dhawan [31] employed ARIMA technique to encounter variation in ER. Kenen and Roderick [32], Thursby and Thursby [33], Vergil [25] used GARCH approach to measure uncertainty in exchange rate. Thursby and Thursby [34], Tavlas et al., [35] used absolute percentage change of ER as measure of uncertainty. Thursby and Thursby [33] formulate Variance of spot exchange rate around its trend for measuring of uncertainty, Akther and Hilton [15], Gotur [16] used moving average standard deviation. Peree and Steiner [5] and Sethenbier and Chow et al., [36] used the long-run exchange rate uncertainty method as a measure of volatility. Olimov and Sirajdinnov 2007 found that as there is no best method to measure volatility in exchange rate but comparing and contrasting empirical techniques is important.

Paul et al., [37] analysed the effect of the nominal exchange rate, Inflation rate, capital stock and foreign direct investment on economic growth in Kuwait by using time series data from 1975-2015. The results confirm that as nominal exchange rate increases, then it leads to a significant positive effect on economic growth. Similarly, Mustafa and Rashid [38] find a negative effect of exchange rate volatility on different macroeconomic variables in Pakistan. Abbas, S. K et al., [39] analyses the effect of the revaluation of fixed assets on future performance of firms in Pakistan. They analyse the cement sector of Pakistan. Results revealed that revaluation of fixed assets puts a negative impact on future firm performance in cement companies. Saad Khan and Rashid Ali [40] studied the relationship between export demand and exchange rate volatility in Pakistan. They employed autoregressive distributed lag model (Bound test). The result confirms that the real effective exchange rate has an insignificant negative effect on aggregate export demand of Pakistan.

The empirical application of the gravity model within panel framework has produced a remarkable change in the empirical literature on the effect of trade flow by uncertainty in exchange rate. The empirical result in estimating the bilateral trade relation has successful or has many advantages over traditional model. The majority of the studies relating to developing countries use traditional explanatory variables to explain export demand function, i.e. income and price with additional variable of exchange rate volatility. 


\section{Gravity Model}

This model is similar to the model employed by Goldstein [41], Vergil [42], McKenzie [21], Chowdhury [43] and Saad [44].

$$
E X_{d}=f \text { (real income of export Partner, relative Price) }
$$

For empirical estimation form

$$
\ln \left(E X_{d}\right)=\alpha_{0}+\alpha_{1} \ln Y_{t}+\alpha_{2} \ln P_{t j}+\mu_{t}
$$

To integrate the effect of volatility in ER an additional variable of volatility added to the conventional trade model the shape of the model become

$$
\ln \left(E X_{d}\right)=\alpha_{0}+\alpha_{1} \ln Y_{t}+\alpha_{2} \ln P_{t}+\alpha_{3} \ln V_{t}+\mu_{t}
$$

Here $E X_{d}$ is total Export of Pakistan, Yt is the real foreign income, $\mathrm{P}_{\mathrm{t}}$ is real exchange rate, and $V_{t}$ is the exchange rate Volatility. Moreover, $\alpha_{i}$ represent the parameter where $\mathrm{i}=0,1,2,3$.

This model previously used by Bergstrand [45], Leamer and Levisohn [46] and Aristotelous [17], Chan et al., [36]. Furthermore, a reduced form of a gravity model is known as the general equilibrium of demand and supply form, as revealed by Bergstrand $[47,45]$ and Thursby and Thursby [33].

The gravity model has an outstandingly, reliable history of success as an empirical model. The gravity model has applied in international trade studies extensively with empirical success. Tinbergen [48], Poyhoenen [49] and Lineman [50] are pioneer in employing gravity model in empirical analysis. Theoretical background put forward Anderson [51], Bergstrand [47, 45] later. Some studies discussed here are related to our proposition. Koo et al., [52] analysed the uncertainty in ER on bilateral trade and found negative significant effect on bilateral trade. Dell Arica [53] examines volatility in ER and its effect on bilateral trade flow in western European countries, found negative effect on bilateral trade. Aristotelous [17] use gravity model and found insignificant effect on bilateral export between United States of America and United Kingdom. Tenreyro [54] found insignificant effect on trade by use of gravity model. Clark, Tamirs and Wei [18] found negative significant effect on trade through gravity model technique.

Previous study relative to Pakistan similar to our preposition is quite limited. Kumar and Dhawan [31] was the first study related to volatility in ER impact on Pakistan aggregate exports using bilateral exports data with major trading partner United States of America, United Kingdom, Japan and West Germany, use standard deviation approach to measure volatility use nominal and real data suggest an insignificant negative effect on trade. Bahamani Oskooee and Payesteh [55] examine the exchange rate volatility on aggregate exports of Pakistan found a significant negative effect. Arize, Malindretos and Kasibhatla [56] empirically explore the relation between uncertainties in exchange rate and trade flow found significant negative effect. Nishat and Khalid Mustafa [38] studied the impact of exchange rate volatility on exports growth of Pakistan using leading trade partners of Pakistan data set for the period 1991:3Q to 2004:2Q used errorcorrection techniques to establish the empirical relationship. They found that volatility in exchange rate has significant negative effects in long run and short run with Australia, New Zealand, United States of America and United Kingdom, and countries like Bangladesh and Malaysia no empirical relationship had observed between export growth and exchange rate volatility. A. $\mathrm{R}$ Kemal [57] used three stages least square (3SLS) techniques to estimate exchange rate instability impact on exports. He found that exchange rate instability does not have significant impact on exports. So Pakistan exports were not one of those countries where exchange rate instability is the major problem that could affect the decision making of exporters. Anjum Aqeel and Nishat [58] studied empirically determined the long-run relationship between exchange rate volatility and exports growth of Pakistan. A multi-variant cointegration technique employed on quarter data during 1982:Q1 to 2000:Q4. They found that exchange rate volatility has significant negative impact on exports in long as well as short run. Alam and Ahmed [59] estimate the exports demand Pakistan including volatility of exchange rate as an explanatory variable for the period 1982Q1-2008Q2 used ARDL approach. They suggested that the volatility of real effective exchange rate has adversely affected Pakistan's aggregate exports in long run and insignificant effect in short run. Kumar and Dahwan [31] were the first to analyse the effect of volatility in exchange rate on bilateral export of Pakistan from its major trading partners. The results revealed mixed effect of volatility in exchange rate on bilateral export.

From the above discussion, we can conclude that empirical survey over Pakistan studies leads to the same mixed picture of the result, with many studies found no significant effect, or some found significant, no systematic effect in one direction or the other. In the context of Pakistan, a more empirical contribution is needed especially at disaggregate level which has been more successful in obtaining a statistically significant relationship between volatility and trade with more 
careful attention given to estimation technique and measure of volatility.

\section{MATERIAL AND METHODS}

This study conducts on bilateral exports data and gravity model used. Jan Tinbergen [48] was the first who used the Newton gravity model in explaining the bilateral trade between two countries. If variables such as language relationships, tariffs, contiguity, access to sea, colonial history, exchange rate regimes, and other variables of interest added to the gravity model, it has known as generalised gravity model. The current study employed generalized gravity model similar to Bergstrand [45] for explaining the export performance of Pakistan with bilateral exchange rate volatility measure and exchange rate regimes in panel framework.

Empirical model for aggregate bilateral trade in current studies includes benchmark variables of gravity model that include economic sizes of countries involved in transaction (i.e. exporter and exports partner) and distance between transaction countries with additional variable of relative prices of Pakistan export, bilateral exchange rate volatility and dummy for freefloating exchange rate regime this is similar to Bergstrand [47] and Aristotelous [17].

$$
\mathrm{X}_{\mathrm{pak}, \mathrm{j}, \mathrm{t}}=\mathrm{f}\left(\mathrm{GDP}_{\mathrm{pak}, \mathrm{t}}, \mathrm{GDP}_{\mathrm{j}, \mathrm{t}}, \mathrm{RP}_{\mathrm{pak}, \mathrm{j}, \mathrm{t}}, \mathrm{Dis}_{\mathrm{pak}, \mathrm{j}}, \mathrm{V}_{\mathrm{pak}, \mathrm{j}, \mathrm{t}}, \mathrm{D}_{\mathrm{reg}}\right)
$$

Here, $X_{\text {pak,j,t }}=$ Value of bilateral export of Pakistan to the $j^{\text {th }}$ country in ' $t$ ' period. GDP $_{\text {pak, },}=$ Gross Domestic product of Pakistan in ' $t$ ' period. GDP $_{\mathrm{j}, \mathrm{t}}$ $=$ Gross domestic product of $j^{\text {th }}$ country in ' $t$ ' period. $\mathrm{RP}_{\text {pak, }, \mathrm{t}}=$ Relative price of Pakistan exports to jth country in ' $t$ ' time. Dis ${ }_{\mathrm{pak}, \mathrm{j}}=$ Distance between Pakistan capital to $\mathrm{j}^{\text {th }}$ country capital. $\mathrm{V}_{\mathrm{pak}, \mathrm{j}, \mathrm{t}}=$ Volatility measure of bilateral exchange rate Pakistan rupee to $\mathrm{j}^{\text {th }}$ country currency in ' $t$ ' time. $D_{\text {reg }}=$ Dummy for free-floating exchange rate regime in Pakistan.

The above model is in a log-linear form, so coefficients represent the elasticities of each dependent variable.

$$
\begin{aligned}
& \ln \left(X_{p a k, j, t}\right)=\beta_{0}+\beta_{1} \ln \left(\mathrm{GDP}_{\mathrm{pak}, \mathrm{t}}\right)+\beta_{2} \ln \left(\mathrm{GDP}_{\mathrm{j}, \mathrm{t}}\right)+\beta_{3} \ln \left(\mathrm{RP}_{\mathrm{pak}, \mathrm{j}, \mathrm{t}}\right)+\beta_{4} \ln \left(D i s_{p a k, j}\right)+\beta_{5} \ln \left(V_{p a k, j, t}\right)+\beta_{6} \mathrm{D}_{\mathrm{reg}}+ \\
& \epsilon_{\mathrm{t} \ldots \ldots \ldots} \text { (1.b) }
\end{aligned}
$$

Here $\beta_{0}, \beta_{1}, \beta_{2}, \beta_{3}, \beta_{4}, \beta_{5}$ and $\beta_{6}$, are parameters and $\epsilon_{t}$ represent error term. Expected sign of $\beta_{3}$ and $\beta_{4}<$ 0 i.e. negative; $\beta_{1}, \beta_{2}>0$ i.e. positive. The sign of $\beta_{5}$ and $\beta_{6}$ are ambiguous. Cross invariant effect of Pakistan
$\left(\mathrm{GDP}_{\text {pak,t }}\right)$ can controlled by following the Krugman and Maurice [60] suggestion to use the ratio form of economics sizes ie. $\mathrm{GDP}_{\mathrm{j}, \mathrm{t}} / \mathrm{GDP}_{\mathrm{pak}, \mathrm{t}}$ the model take the following form:

$$
\begin{aligned}
& \ln \left(X_{p a k, j, t}\right)=\gamma_{0}+\gamma_{1} \ln \left(\mathrm{GDP}_{\mathrm{j}, \mathrm{t}} / \mathrm{GDP}_{\mathrm{pak}, \mathrm{t}}\right)+\gamma_{2} \ln \left(\mathrm{RP}_{\mathrm{pak}, \mathrm{j}, \mathrm{t}}\right)+\gamma_{3} \ln \left(D i s_{p a k, j}\right)+\gamma_{4} \ln \left(V_{p a k, j, t}\right)+\gamma_{5} \mathrm{D}_{\mathrm{reg}}+ \\
& \epsilon_{\mathrm{t} \ldots \ldots \ldots \ldots \ldots}(1 . \mathrm{c})
\end{aligned}
$$

Here $\gamma_{0}, \gamma_{1}, \gamma_{2}, \gamma_{3}, \gamma_{4}$ and $\gamma_{5}$, are parameter and $\epsilon_{\mathrm{t}}$ represents error term. The expected sign of $\gamma_{2}$ and $\gamma_{3}<$ 0 i.e. negative and $\gamma_{1}>0$ i.e. positive. The sign of $\gamma_{4}$ and $\gamma_{5}$ are ambiguous.

\section{Exchange Rate Volatility Measurement}

The current study measures the exchange rate volatility through different approaches. Measures for volatility consider in this study are Absolute percentage change of the exchange rate approach, moving average standard deviation approach, ARIMA approach, ARCH and GARCH approach.

\section{GARCH approach}

Each measure of volatility can report different results on trade, as McKenzie [30] verifies different methods may outlay different results and conclusion because the assumption of measuring volatility with each method is different. Measures for volatility consider in the current study are Absolute percentage change of the exchange rate approach, moving average standard deviation approach, ARIMA approach, ARCH approach and GARCH approach. In measuring volatility, current study employed bilateral exchange rate data because each country behaves differently in different magnitude of volatility. In other words, riskaverse behaviour is different in each country. In current, study both nominal bilateral exchange rate employed in computing the volatility.

\section{Moving Average Approach}

Moving average method is one of the popular methods of measuring uncertainty in the exchange rate. The uncertainty can be measured based on ' $\mathrm{m}$ ' period average value comparing with the current value. The formula of computing the volatility by moving average of standard deviation of exchange rate is as follows

$$
V E N E_{t}=\left\{\frac{1}{m} \sum_{i=1}^{m}\left(E R_{t}-E R_{t-1}\right)^{2}\right\}^{\frac{1}{2}}
$$

Here ' $\mathrm{m}$ ' is the order of moving average, $\mathrm{ER}_{\mathrm{t}}$ is the bilateral nominal exchange rate at ' $t$ ' period, $E_{t-1}$ is the bilateral nominal exchange rate at $(\mathrm{t}-1)$ period, this method used Kumar and Dhawan [31], Akther and Hilton [15], Gotur [16], Nishat et al., [61] and many 
others. We denote volatility by $\mathrm{VENE}_{\mathrm{t}}$ The volatility in bilateral nominal exchange rate value at year-end of last four-year $(\mathrm{m}=4)$ use the moving average method to compute the volatility

\section{ARIMA Approach}

The ARIMA approach was initiate by Asseery and Peel [23], Mclovr [62] to measure the volatility in the exchange rate. Volatility measured through, ARIMA denoted by VARIMA . In ARIMA lags term of dependent variable represent autoregressive (AR) and lags of error term represents moving average (MA). Nominal exchange rate annual data is used to measure the volatility in bilateral exchange rate. The functional form for estimating the volatility through ARIMA $(1,1)$ procedure is as follows.

$$
\widehat{E R}_{t}=\emptyset+\alpha_{1}\left(E R_{t-1}\right)+\beta_{0} \mu_{t}+\beta_{1} \mu_{t-1}
$$

Here $\mathrm{ER}_{\mathrm{t}}$ represents the Bilateral nominal exchange rate at time t. $\mu_{t}$ represents an uncorrelated random error term with zero mean and constant variance $\sigma^{2}$. The estimated binomial exchange rate is the sum of the constant term $(\varnothing)$ plus some proportion of its value at (t-1) plus the moving average of current and past error term. VARIMA at time $t$ is the difference of estimated and actual bilateral exchange rate.

\section{ARCH and GARCH APPROACH}

The method found in recent studies is Autoregressive Conditional Heteroskedasticity (ARCH) model and Generalized Autoregressive Conditional Heteroskedasticity (GARCH). It is slightly different in these two approaches. These two approaches employed to capture the fluctuation in time series. The ARCH model proposed by Engle [63]. This approach initially used by Pozo [64], McKenzie and Brooks [20],
McKenzie [21] to measure the volatility in the exchange rate. GARCH model was put forward by Bollerslev [65]. To measure the volatility this approach is employed by Thursby and Thursby [33], Olimov and Sirajiddinov 2007 and Vergil, H [25]. In Pakistan context, this method is used by Alam [66] to measure the uncertainty in exchange rate.

ARCH model is used to forecast the mean and variance of the exchange rate from past values. The $\mathrm{ARCH}$ model assumes that the variance of future is the equally-weighted average of the squared residuals of the past values for supposing ' $n$ ' values. In our case exchange rate volatility could measure by regression of exchange rate on its lag value and generating the residual series. The volatility is equal to the sum of $n$ residual term equally weighted.

$$
\begin{array}{r}
E R_{t}=\beta_{0}+\beta_{1} E R_{t-1}+\varepsilon_{t} \\
V A R C H_{t}=w_{0} \varepsilon_{t}+w_{0} \varepsilon_{t-1}+w_{0} \varepsilon_{t-2}+\ldots .+w_{0} \varepsilon_{t-n}
\end{array}
$$

Here 'ER' represent bilateral exchange rate, $\varepsilon_{t}$ represent residual, ' $\mathrm{t}$ ' represents time and 'VARCH' represent the exchange rate volatility, ' $\mathrm{w}_{\mathrm{o}}$ ' represent weight assign to each included lag residual and ' $n$ ' represent the number of lags in current study $n=2$.

GARCH model also assumes the weighted average of the square of the residuals of all past values but in declining proportion. In such a way, the more recent value weight higher and so on. In GARCH approach, the weight term never assigns zero weight to past value. The GARCH model that has employed is $\operatorname{GARCH}(1,1)$ with the help of econometric software EViews. In parentheses $(1,1)$ the first value represents the number of autoregressive lags term in our case it is 1 , and second number represents the number of moving average lags which is also 1 .

GARCH technique is more appropriate than the ARCH technique because of two reasons. First, in $\mathrm{ARCH}$ model, the equal weight given to all included past values for supposes ' $n$ ' values; but one may think that most recent value should have higher weights because of relatively strong influence from the recent value as it assumed in GARCH model. Second, assumption of zero weight for the observation above ' $n$ ' i.e. (n-i); here $\mathrm{i}$ is $1,2,3 \ldots \ldots$ in $\mathrm{ARCH}$ model while weight assign in GARCH never become zero although the weight was diminishing. The procedure used to obtain the volatility through GARCH approach is as follows:

$$
\begin{gathered}
E R_{t}=\beta_{0}+\beta_{1} E R_{t-1}+\varepsilon_{t} \\
V G A R C H_{t}=w_{0} \varepsilon_{t}+w_{1} \varepsilon_{t-1}+w_{2} \varepsilon_{t-2}+\ldots \ldots+w_{n} \varepsilon_{t-n}
\end{gathered}
$$

Here ER represent bilateral exchange rate, $\varepsilon_{t}$ Represent the residual, $\mathrm{t}$ is the time, and VGARCH is the exchange rate volatility measure through GARCH. $\mathrm{W}_{\mathrm{i}}$ represent the weight assign to each lag residual terms. $\mathrm{i}$ is the number of residual terms includes $\mathrm{i}=$
$1,2,3,4 \ldots . . n$. ' $n$ ' represents the number of lags in current study $n=2$.

$\mathrm{X}_{\text {pak, }, \mathrm{t}, \mathrm{i}}$ is the Bilateral aggregate exports of Pakistan to $\mathrm{j}^{\mathrm{th}}$ country. It defined as the total amount of 
goods and services provided by Pakistan to $\mathrm{j}^{\text {th }}$ country. Bilateral aggregate exports between Pakistan and exporting countries which include in current study are USA, UK, Hong Kong, Germany and UAE are measured in US dollar (US \$) the data is extracted from state bank of Pakistan. (Handbook statistics of Pakistan Chapter 8 section 4).

UVIX $_{\text {pak,t }}$ Unit value index of Pakistan export, extracted from state bank of Pakistan (Handbook of statistics Chapter 8 sections 4).

Real Gross Domestic Product $\left(\mathrm{GDP}_{\text {Pak,t }}\right)$ of Pakistan calculated by nominal gross domestic product in US \$ divided by gross domestic deflator.

$$
G D P_{p a k, t}=\frac{\text { Nominal GDP }}{\text { GDak }, t}
$$

The data of Nominal gross domestic Product of Pakistan $\left(\mathrm{NGDP}_{\mathrm{pak}, \mathrm{t}}\right)$ and GDP deflator ${ }_{\mathrm{pak}, \mathrm{t}}$ of Pakistan extracted from IFS (various issues).

Real Gross Domestic Product $\left(\mathrm{GDP}_{\mathrm{j}, \mathrm{t}}\right)$ of chosen export partners computed by nominal gross domestic product of the $\mathrm{j}^{\text {th }}$ country in US dollar (\$) divided by gross domestic deflator of $\mathrm{j}^{\mathrm{th}}$ country.

$$
G D P_{j, t}=\frac{{\text { Nominal } G D P_{j, t}}_{G D \text { deflator }_{j, t}}}{G \text { flat }}
$$

The data of GDP of $\mathrm{j}^{\text {th }}$ country and GDP deflator of the $\mathrm{j}^{\text {th }}$ country at $\mathrm{t}$ time is extracted from IFS various issues.

The relative price index of aggregate export $\left(\mathrm{RP}_{t}\right)$ is the ratio of the unit price index of Pakistan exports (UVIX $\left.{ }_{p a k, t}\right)^{2}$ to consumer price index of $j^{\text {th }}$ partner $\left(\mathrm{CPI}_{\mathrm{j}, \mathrm{t}}\right)$ at $\mathrm{t}$ time. This method is similar to those employed by Alam, S., and Ahmed, Q. M [59].

$$
R P_{p a k, j, t}=\frac{U V I X_{p a k, t}}{C P I_{j, t}}
$$

$\mathrm{CPI}_{\mathrm{j}, \mathrm{t}}$ Consumer price index defined as the weighted average of prices of a basket of consumer goods and services at $t$ period. The consumer price index of chosen countries is extracted from IFS various issues.

Dis $_{\text {pak,j }}$ Distance data is time-invariant taken in $\mathrm{Km}$, it defined as the distance between the capital city of Pakistan (Islamabad) and to the chosen capital city of the $\mathrm{j}^{\text {th }}$ country. Freight rate can also be employed as a proxy in different studies to nullify the time-invariant problem. The distance data (in $\mathrm{Km}$ ) has extracted from CEPII.

\footnotetext{
${ }^{2}$ CPI of Pakistan can also be used instead of UVIX. Unit value index of export (UVIX) only export commodity prices will be include. If CPI is used goods which are not exported also included as well as import goods.
}

$\mathrm{NE}_{\mathrm{pak}, \mathrm{j}, \mathrm{t}}$ is a bilateral nominal exchange rate, defined as the value of Pakistan rupees per unit currency of $j^{\text {th }}$ country at $t$ period. The bilateral nominal exchange rate extracted from Pakistan Economics survey various issue.

$\mathrm{D}_{\text {reg }}$ is a dummy variable for the free-floating exchange rate regime. As the study comprises on Pakistan from 1982 to 2015 that contains only two types of exchange rate regime, i.e. managed floating and free-floating. For the period 1982-2000 managed floating exchange rate regime employed and after 2000 to till free-floating exchange rate regime 2015.

$D_{\text {reg }}=0$ for managed floating exchange rate regime and

$D_{\text {reg }}=1$ for free-floating exchange rate regime.

\section{Empirical Analysis}

The empirical analysis is done in such a way to achieve three main objectives concerned with current studies. First, measure the influence of exchange rate volatility on aggregate exports. Second: to incorporate the presence of free-floating exchange rate regime in the model. Third: to incorporate the effect of different techniques to measure exchange rate volatility on aggregate exports.

Estimation techniques of gravity model previously used in empirical studies are panel least square, one way fixed (i.e. cross or time) effect, two way fixed (both time and cross) effect and one-way random effect model (time or cross). In estimation through the fixed-effect model, the basic assumption is made for intercept (i.e. constant) term is different for both country and period with the same coefficients (slope) of dependent variables. In estimation through random effect model or error component model the basic assumption is also made for intercept term that is assumed to be random outcome across country and time But the current study estimates two way cross and time fixed effect (i.e. country wise and time-wise) by controlling time-invariant variable distance by following Cheng [67] and cross invariant variables, i.e. GDPPAK and Dreg, by using ratio form of GDPs (i.e. GDPJ/GDPPAK) previously done by Kurgmen [68]. The empirical justification among fixed effect model and panel least square did through f-test - furthermore, Hausman test used for selection between fixed effect model and random effect model. 


\section{RESULTS AND DISCUSSION}

As we quest for the better functional form between random and fixed effect model the Hausman test used (see appendix Table-3) the chi - statistic of Hausman test indicates that random effect model is inappropriate in other words it is better to use fixed-effect model. F-test criteria for the selection of model between pools least square model (unrestricted model) and fixed effect model (restricted model) previous done by Gujarat [69] and Aristotelous [17]. The null hypothesis of F-test: fixed effect model (i.e. restricted model) is better than the unrestricted model. However, ${ }^{3}$ f-test between pool and two way (time and cross) fixed-effect model concludes the rejection of null hypothesis or in other words pooled least square model (i.e. unrestricted model) is appropriate over two-way (cross and time) fixed-effect model, i.e. restricted model.

In next phase of empirical analysis (Table-3) estimation of the model in four different ways by eliminating the different independent variable to see the importance of exchange rate volatility and a dummy for exchange rate regime combine and separate effect are done. In column (a) model is estimated on its original form as described in (section 3) model in column (b) estimate after eliminating dummy for free-floating exchange rate regime (DREG). In column (c) estimates are calculated, eliminating exchange rate volatility variant. In column (d) estimate model after eliminating both volatilities in exchange rate as well as dummy for free-floating exchange rate regime.

Table-1: Aggregate Exports of Pakistan (generalised gravity model)

\begin{tabular}{|c|c|c|c|c|}
\hline & $\begin{array}{l}\text { Column } \\
\text { (a) }\end{array}$ & $\begin{array}{l}\text { Column } \\
\text { (b) }\end{array}$ & $\begin{array}{l}\text { Column } \\
\text { (c) }\end{array}$ & $\begin{array}{l}\text { Column } \\
\text { (d) }\end{array}$ \\
\hline Constant & $\begin{array}{l}5.699 * \\
(2.77) \\
\end{array}$ & $\begin{array}{l}7.959^{*} \\
(4.085) \\
\end{array}$ & $\begin{array}{l}6.141^{*} \\
(3.158)\end{array}$ & $\begin{array}{l}7.915^{*} \\
(4.235) \\
\end{array}$ \\
\hline $\begin{array}{l}\text { Log(GDPJ / } \\
\text { GDPPAK) }\end{array}$ & $\begin{array}{l}0.111 * \\
(2.06)\end{array}$ & $\begin{array}{l}0.595 * \\
(4.795)\end{array}$ & $\begin{array}{l}0.3099 * \\
(4.709)\end{array}$ & $\begin{array}{l}0.576 * \\
(8.572)\end{array}$ \\
\hline $\log (\mathrm{DIS})$ & $\begin{array}{l}-0.343 * * \\
(-1.732)\end{array}$ & $\begin{array}{l}-0.529 * \\
(-2.288) \\
\end{array}$ & $\begin{array}{l}-0.035 * * \\
(-1.60)\end{array}$ & $\begin{array}{l}-0.630^{*} \\
(-3.133)\end{array}$ \\
\hline $\log (\mathrm{RP})$ & $\begin{array}{l}-0.589^{*} \\
(-3.142)\end{array}$ & $\begin{array}{l}-0.3113 \\
(-1.431)\end{array}$ & $\begin{array}{l}-0.140 * * \\
(-1.687)\end{array}$ & $\begin{array}{l}-0.461^{*} \\
(-2.746)\end{array}$ \\
\hline LOG(V) & $\begin{array}{l}0.125 * * \\
(1.751)\end{array}$ & $\begin{array}{l}-0.1090 \\
(-0.989)\end{array}$ & ---- & ---- \\
\hline DREG & $\begin{array}{l}1.316^{*} \\
(6.509)\end{array}$ & ---- & $\begin{array}{l}1.178^{*} \\
(6.294)\end{array}$ & ---- \\
\hline Adj. $R^{2}$ & 0.72 & 0.50 & 0.51 & 0.50 \\
\hline f-statistics & 31.83 & 30.01 & 42.23 & 30.81 \\
\hline $\begin{array}{l}\text { No. of } \\
\text { observation }\end{array}$ & 145 & 145 & 157 & 157 \\
\hline
\end{tabular}

The figures in parentheses are t- statistics; White crosssection standard error and covariance (d.f. corrected)

*Show significance at $5 \%$ level, $* *$ show significance at $10 \%$ level

Note; here, volatility measure VENE is used as exports determinant, and dependent variable $\mathrm{X}_{\mathrm{pak}, \mathrm{j}, \mathrm{t}}$. Source: Author's Calculation

${ }^{3} \mathrm{~F}$-calculated value is $77.06>\mathrm{f}$-critical value at $5 \% 3.07$; it conclude it may be inappropriate to use restricted model.
The standard features of the gravity model work well in the model. As the model estimates in logarithm form the coefficients represent the elasticity of each determinate of exports function. The signs of the ratio of masses (i.e. GDPJ / GDPPAK), distance and relative prices are according to theory in term of magnitude and sign. The coefficients of GDPJ / GDPPAK is 0.111 to 0.595 means $1 \%$ increase in ratio of GDPJ / GDPPAK increase aggregate exports by $0.11 \%$ to $0.595 \%$. The coefficients of distance are negative and significant at $10 \%$ significance level. It means Pakistan's export decrease as the distance increase. The coefficients of related price are in range of 0.140 to 0.589 means $1 \%$ increase in relative prices of exporting commodities depresses the aggregate exports of Pakistan by $0.14 \%$ to $0.58 \%$.

The dummy for free-floating exchange rate regime found to be positive and significant at $5 \%$ significance level. The coefficients of dummy for freefloating exchange rate regime range from 1.316 and 1.178 means the free-floating exchange rate regime favour the aggregate exports by $1.31 \%$ and $1.17 \%$. Column (a) and (c) indicate that the free-floating exchange rate regime had positive influence on the aggregate exports of Pakistan with their major export partners. In other words empirical results from Table-1 suggest that exchange rate regime is one of the significant determinants of aggregate exports of Pakistan. Free-floating exchange rate regime helps to achieve equilibrium in balance of payment.

The exchange rate volatility is positive and significant effect with a dummy for free-floating exchange rate regime as shown in Table-1 column (a) but negative and insignificant without dummy for exchange rate regime as shown in Table-3 column (b). An important conclusion is that it is a good deal to apply exchange rate volatility with dummy for exchange rate regime. The result incorporates in column (b) is in-line with study of Kumar and Dhawan [31] AR Kemel [57] they also found no effect of exchange rate volatility on exports. While contrary with Aqeel [58], Akther and Hilton [15], Pozo [64], Arize et al., [26], Chowdrhury [70] which suggested that consistent strong influence of exchange rate volatility depresses exports.

The ${ }^{4}$-test between model present in column (a) and Cheng Wall model [71] present in column (b); suggest that Cheng Wall model [71] is inappropriate. The ${ }^{5}$ f-test between column (a) and (c) suggest that transformation model, i.e. (restricted model of column (c) is not appropriate. In other words it is better to use exchange rate volatility with dummy for free-floating

\footnotetext{
${ }^{4} \mathrm{f}$ - calculated value is $91.682>\mathrm{f}$-critical value at $5 \% 3.07$; it conclude it may be inappropriate to use restricted model.

${ }^{5} \mathrm{f}$ - calculated value is $28.30>\mathrm{f}$-critical value at $5 \% 3.92$; it conclude it may be inappropriate to use restricted model.
} 
exchange rate regime in explaining aggregate exports of Pakistan. So, exchange rate volatility has positive effect on aggregate exports with positive effect of freefloating exchange rate regime.

\section{Robustness}

In the current phase of empirical analysis, different measures of exchange rate volatility applied in the model to check robustness. Empirical results in Table-2 show results of different exchange rate volatility measures with dummy for exchange rate regime. The sign of exchange rate volatility measures is negative as well as positive in case of VENE and VGARCH it is significant at $10 \%$ significant level but insignificant in case VARIMA and VARCH. The result obtained was in line with Kumar and Dhawan [31] suggesting that different measures of volatility in exchange rate of Pakistan show different effect concerning sign but all insignificant at 5\% significant level on aggregate exports of Pakistan. The difference in sign and magnitude is due to assumption behind each of the measure of volatility in exchange rate. We can conclude that the sign of volatility is ambiguous on aggregate export and it may influence the exports of Pakistan.

Table-2: Effect of a different measure of volatility in the exchange rate on aggregate exports of Pakistan

\begin{tabular}{|l|l|l|l|l|}
\hline $\begin{array}{l}\text { Volatility } \\
\text { measure }\end{array}$ & VENE & VARIMA & VARCH & VGARCH \\
\hline Constant & $\begin{array}{l}5.699^{*} \\
(2.77)\end{array}$ & $\begin{array}{l}7.071^{*} \\
(3.07)\end{array}$ & $\begin{array}{l}6.748^{*} \\
(4.021)\end{array}$ & $\begin{array}{l}7.448^{*} \\
(4.269)\end{array}$ \\
\hline $\begin{array}{l}\log (\mathrm{GDPJ} \\
\text { I }\end{array}$ & $0.111^{*}$ & $0.145^{*}$ & $0.333^{*}$ & $0.4314^{*}$ \\
GDPPAK) & $(2.06)$ & $(1.189)$ & $(3.822)$ & $(3.833)$ \\
\hline Log(DIS) & $-0.343^{*}$ & -0.131 & -0.0282 & $-0.130^{* *}$ \\
& $(-1.732)$ & $(-1.471)$ & $(-1.274)$ & $(-1.600)$ \\
\hline Log(RP) & $-0.589^{*}$ & $-0.467^{* *}$ & $-0.277^{* *}$ & -0.263 \\
& $(-3.142)$ & $(-1.73)$ & $(-1.540)$ & $(-1.466)$ \\
\hline DREG & $1.316^{*}$ & $0.972^{*}$ & $1.249^{*}$ & $1.1877^{*}$ \\
& $(6.509)$ & $(4.199)$ & $(7.163)$ & $(6.987)$ \\
\hline LOG(V) & $0.125^{* *}$ & 0.1045 & -0.037 & $-0.102^{* *}$ \\
& $(1.751)$ & $(1.105)$ & $(-1.058)$ & $(-1.723)$ \\
\hline Adj. R ${ }^{2}$ & 0.72 & 0.44 & 0.51 & 0.52 \\
\hline f-statistics & 31.83 & 13.88 & 33.35 & 34.14 \\
\hline $\begin{array}{l}\text { No. of } \\
\text { observation }\end{array}$ & 145 & 83 & 153 & 153 \\
\hline \multicolumn{2}{|l|}{} & & & \\
\hline
\end{tabular}

The figures in parentheses are t- statistics; White cross-section standard error and covariance (d.f. corrected)

*Show significance at 5\%level, **show significance at $10 \%$ level Note; Dependent variable $\mathrm{X}_{\text {pak, }, \mathrm{t}}$ Source: Author's Calculation

\section{Appendix}

Empirical Result Section

Table-3: Estimation of Aggregate Exports (Cross and Time fixed effect)

\begin{tabular}{|c|c|c|}
\hline & $\begin{array}{ll}\text { Fixed } & \text { Effect } \\
\text { Model } & \end{array}$ & $\begin{array}{l}\text { Random } \\
\text { Effect Model }\end{array}$ \\
\hline Constant & $\begin{array}{l}6.9500^{*} \\
(1.94)\end{array}$ & $\begin{array}{l}5.27 * \\
(4.31)\end{array}$ \\
\hline Log(GDPJ/GDPPAK) & $\begin{array}{l}1.8032 * \\
(1.989)\end{array}$ & $\begin{array}{l}0.069 \\
(0.750)\end{array}$ \\
\hline $\log (\mathrm{RP})$ & $\begin{array}{l}-1.5010^{*} \\
(-2.175)\end{array}$ & $\begin{array}{l}-0.467 * \\
(-2.782) \\
\end{array}$ \\
\hline LOG(V) & $\begin{array}{l}-0.119^{*} \\
(-2.775)\end{array}$ & $\begin{array}{l}-0.691 \\
(-0.750)\end{array}$ \\
\hline UK -Constant & -0.547 & $9.55 \mathrm{E}-12$ \\
\hline Hong Kong-Constant & 3.431 & $1.20 \mathrm{E}-11$ \\
\hline UAE-Constant & 2.382 & $4.50 \mathrm{E}-11$ \\
\hline Germany-Constant & -1.438 & $-2.38 \mathrm{E}-11$ \\
\hline $1983-\mathrm{C}$ & -0.24321 & $-4.27 \mathrm{E}-11$ \\
\hline 1984-C & -0.23346 & -0.134751 \\
\hline $1985-\mathrm{C}$ & -0.277104 & -0.178064 \\
\hline $1986-\mathrm{C}$ & -0.443639 & -0.162409 \\
\hline $1987-\mathrm{C}$ & -1.036460 & -0.372323 \\
\hline $1988-\mathrm{C}$ & -0.494733 & -0.236613 \\
\hline $1989-\mathrm{C}$ & -0.556452 & -0.226345 \\
\hline $1990-\mathrm{C}$ & -0.197825 & -0.118589 \\
\hline $1991-\mathrm{C}$ & 0.093055 & -0.029494 \\
\hline $1992-\mathrm{C}$ & -0.052004 & -0.035142 \\
\hline $1993-\mathrm{C}$ & 0.672187 & 0.171128 \\
\hline $1994-\mathrm{C}$ & -0.222677 & 0.113468 \\
\hline $1995-\mathrm{C}$ & -0.029327 & 0.139273 \\
\hline $1996-\mathrm{C}$ & 0.171111 & 0.182087 \\
\hline $1997-\mathrm{C}$ & 0.032104 & 0.186349 \\
\hline $1998-\mathrm{C}$ & 0.089429 & 0.197497 \\
\hline $1999-\mathrm{C}$ & -0.149016 & 0.175045 \\
\hline $2000-\mathrm{C}$ & -0.135733 & 0.194132 \\
\hline $2001-\mathrm{C}$ & -0.191835 & -0.129516 \\
\hline $2002-\mathrm{C}$ & -0.324334 & -0.132123 \\
\hline $2003-\mathrm{C}$ & -0.250460 & -0.079413 \\
\hline $2004-\mathrm{C}$ & -0.048449 & -0.049394 \\
\hline $2005-\mathrm{C}$ & 0.035939 & -0.026872 \\
\hline $2006-\mathrm{C}$ & 0.137105 & 0.004049 \\
\hline $2007-\mathrm{C}$ & 0.071513 & 0.011544 \\
\hline $2008-\mathrm{C}$ & 0.441020 & 0.026311 \\
\hline $2009-\mathrm{C}$ & 0.384042 & -0.009488 \\
\hline $2010-\mathrm{C}$ & 0.415446 & 0.019837 \\
\hline $2011-\mathrm{C}$ & 0.849198 & 0.129449 \\
\hline $2012-\mathrm{C}$ & 0.921598 & 0.116850 \\
\hline $2013-\mathrm{C}$ & 0.905069 & 0.117560 \\
\hline $2014-\mathrm{C}$ & 0.945167 & 0.118766 \\
\hline $2015-\mathrm{C}$ & 0.967862 & 0.128726 \\
\hline Adj. $\mathrm{R}^{2}$ & 0.79 & 0.51 \\
\hline f-statistics & 17.12 & 31.21 \\
\hline \multirow[t]{3}{*}{ No. of observation } & 145 & 145 \\
\hline & & 84.83 \\
\hline & & 3 \\
\hline
\end{tabular}

The figures in parentheses are t- statistics; White cross-section standard error and covariance (d.f. corrected)

*Show significance at 5\%level, **show significance at the $10 \%$ level

Note; here long-run volatility measure VENE is used as export determinant. Dependent variable $\mathrm{X}_{\mathrm{pak}, \mathrm{j}, \mathrm{t}}$ Source: Author's Calculation 


\section{CONCLUSION}

The study attempts to investigate the relation of exchange rate volatility on aggregate exports of Pakistan in the presence of a free-floating exchange rate regime. In attempts to do so, current study employed gravity model, utilises panel bilateral annual data for the period 1982 to 2015 and for empirical analysis panel least square method used. In last f-test used for the selection of better functional form of Pakistan exports. It concluded that an exchange rate volatility measure had shown significant positive effect on aggregate exports of Pakistan the result is similar to Brada and Mendez [13], McKenzie and Brooks [20] and contrary from previous studies in scenario of Pakistan AR Kemal [57], Aqeel [58] and Kumar [72] with different trade models found negative impact or no effect on aggregate exports. Free-floating exchange rate regime has shown positive significant impact on aggregate exports of Pakistan. Its means free-floating exchange rate regime favours to increase exports. Other determinants of bilateral aggregate exports of Pakistan are ratio of market sizes of export partner to exporter (i.e. GDPJ / $\left.\mathrm{GDP}_{\mathrm{PAK}}\right)$ has positive statistically significant effect, distance (DIS) has negatively significant effect this shows Pakistan's exports are distance sensitive and Relative Price (RP) has negative and significant effect on bilateral aggregate exports of Pakistan the coefficient of relative price show inelastic demand of exports goods of Pakistan. While the positive determinant of ratio of market size of export partner to exporter $\left(\mathrm{GDP}_{\mathrm{J}} /\right.$ GDPpak) showing Pakistan's exports goods are income inelastic, The sign of GDPJ / GDPpak, distance and relative price are in line with previous studies such as Aristeolous [17] and Tenreyro [54].

Different measures of exchange rate volatility are used to check the robustness in the result. The result obtained from each measure that included in studies has shown a different impact on aggregate exports of Pakistan. It shows a different technique may outlay different result; it depends upon the assumption of each measuring technique. These results are similar to Baily, Tavlas and Ulan [35] that found mixed effect of each measure of volatility in exchange rate on aggregate exports.

\section{POLICY RECOMMENDATION}

From the above conclusion, as Pakistan is exercising free-floating exchange rate since September 2001 , so, policymaker who is trying to devise policies to promote and diversify exporting activities of Pakistan should aim at stabilising the export market. Floating exchange rate regime should follow because, at aggregate export level, it has positive influence on exports. Secondly Steps should be taken by government to make the export goods price competitive as relative price is highly significant.

\section{REFERENCES}

1. Hooper, P., \& Kohlhagen, S. W. (1978). The effect of exchange rate uncertainty on the prices and volume of international trade. Journal of international Economics, 8(4), 483-511.

2. Ethier, W. (1973). International trade and the forward exchange market. The American Economic Review, 494-503.

3. Cushman, D. O. (1983). The effects of real exchange rate risk on international trade. Journal of International Economics, 15, 45-63.

4. Cushman, D. O. (1986). Has exchange risk depressed international trade? The impact of thirdcountry exchange risk. Journal of international Money and Finance, 5(3), 361-379.

5. Perée, E., \& Steinherr, A. (1989). Exchange rate uncertainty and foreign trade. European Economic Review, 33(6), 1241-1264.

6. Coes, D. V. (1981). The crawling peg and exchange rate uncertainty. In Exchange Rate Rules (pp. 113-139). Palgrave Macmillan, London.

7. Franke, G. (1991). Exchange rate volatility and international trading strategy. Journal of International Money and Finance, 10(2), 292-307.

8. Viaene, J. M., \& De Vries, C. G. (1992). International trade and exchange rate volatility. European Economic Review, 36(6), 1311-1321.

9. Falco, R. C., \& Fish, D. (1992). A comparison of methods for sampling the deer tick, Ixodes dammini, in a Lyme disease endemic area. Experimental \& applied acarology, 14(2), 165-173.

10. Usui, T., Nakamura, E., Kobayashi, K., Maruyama, S., \& Helmstaedt, H. (2003). Fate of the subducted Farallon plate inferred from eclogite xenoliths in the Colorado Plateau. Geology, 31(7), 589-592.

11. De Grauwe, P. (1988). Exchange rate variability and the slowdown in growth of international trade. Staff Papers, 35(1), 63-84.

12. Demers, P. A., Thomas, D. B., Rosenblatt, K. A., Jimenez, L. M., McTiernan, A., Stalsberg, H., ... \& Austin, D. F. (1991). Occupational exposure to electromagnetic fields and breast cancer in men. American Journal of Epidemiology, 134(4), 340-347.

13. Brada-Josef, C., \& José, A. M. (1988). Exchange rate risk, exchange rate regime and the volume of international trade. Kyklos 41(2):263-280.

14. Arize, A. C., Osang, T., \& Slottje, D. J. (2000). Exchange-rate volatility and foreign trade: evidence from thirteen LDC's. Journal of Business \& Economic Statistics, 18(1), 10-17.

15. Akhtar, M. A., \& Hilton, R. S. (1984). Exchange rate uncertainty and international trade: Some conceptual issues and new estimates for Germany and the United States. Federal Reserve Bank. 
16. Gotur, P. (1985). Effects of exchange rate volatility on trade: some further evidence. Staff Papers, 32(3), 475-512.

17. Aristotelous, K. (2001). Exchange-rate volatility, exchange-rate regime, and trade volume: evidence from the UK-US export function (18891999). Economics Letters, 72(1), 87-94.

18. Clark, P., Tamirisa, N., \& Wei, S. J. (2004). A new look at exchange rate volatility and trade flows. (Occasional Paper No. 235). Washington, DC: International Monetary Fund.

19. Bini-Smaghi, L. (1991). Exchange rate variability and trade: why is it so difficult to find any empirical relationship?. Applied economics, 23(5), 927-936.

20. McKenzie, M. D., \& Brooks, R. D. (1997). The impact of exchange rate volatility on German-US trade flows. Journal of International Financial Markets, Institutions and Money, 7(1), 73-87.

21. McKenzie, M. D. (1998). The impact of exchange rate volatility on Australian trade flows. Journal of International Financial Markets, Institutions and Money, 8(1), 21-38.

22. Bailey, M. J., Tavlas, G. S., \& Ulan, M. (1987). The impact of exchange-rate volatility on export growth: some theoretical considerations and empirical results. Journal of Policy Modeling, 9(1), 225-243.

23. Asseery, A., \& Peel, D. A. (1991). The effects of exchange rate volatility on exports: Some new estimates. Economics letters, 37(2), 173-177.

24. Kasman, A., \& Kasman, S. (2005). Exchange rate uncertainty in Turkey and its impact on export volume. METU Studies in Development, 32(1), 4158.

25. Vergil, H. (2002). Exchange Rate Volatility in Turkey and Its Effect on Trade Flows. Journal of Economic \& Social Research, 4(1).

26. Arize, A. C. (1995). The effects of exchange-rate volatility on US exports: an empirical investigation. Southern Economic Journal, 34-43.

27. Caporale, T., \& Doroodian, K. (1994). Exchange rate variability and the flow of international trade. Economics Letters, 46(1), 49-54.

28. Arize, A. C., Kallianotis, I. N., Kasibhatla, K. M., Malindretos, J., \& Panayides, A. (2014). Interrelationship of Key Worldwide Money Market Interest Rates: An Econometric Study of the United States. Journal of Business \& Economic Studies, 20(2).

29. Hwang, L. K., Na, Y., Lee, J., Do, Y., \& Chang, S. (2005). Tetraarylphosphonium Halides as Arylating Reagents in Pd- Catalyzed Heck and Cross- Coupling Reactions. Angewandte Chemie International Edition, 44(38), 6166-6169.

30. McKenzie, M. D. (1999). The impact of exchange rate volatility on international trade flows. Journal of economic Surveys, 13(1):71-106.
31. Kumar, R., \& Dhawan, R. (1991). Exchange rate volatility and Pakistan's exports to the developed world, 1974-85. World development, 19(9), 12251240.

32. Kenen, P. B., \& Rodrik, D. (1986). Measuring and analyzing the effects of short-term volatility in real exchange rates. The Review of Economics and Statistics, 311-315.

33. Thursby, J. G., \& Thursby, M. C. (1987). Bilateral trade flows, the Linder hypothesis, and exchange risk. The Review of Economics and Statistics, 488495.

34. Thursby, M. C., \& Thursby, J. G. (1985). The uncertainty effects of floating exchange rates: Empirical evidence on international trade flows. Exchange rates, trade and the US economy (Year: 153-166). Cambridge: Ballinger.

35. Bailey, M. J., Tavlas, G. S., \& Ulan, M. (1986). Exchange-rate variability and trade performance: evidence for the big seven industrial countries. Review of World Economics, 122(3), 466-477.

36. Chow, N., \& Chien, F. (2002). U.S. Patent Application No. 09/758,884.

37. Paul, F. H., Ali, S. R., Soomro, R., Ali, Q., \& Abbas, S. K. (2018). Exchange Rate Volatility and Economic Growth: Evidence from Kuwait. Eurasian Journal of Analytical Chemistry. 13(6):emEJAC181130.

http://www.eurasianjournals.com/Exchange-RateVolatility-and-Economic-Growth-Evidence-fromKuwait,104469,0,2.html

38. Mustafa, K., Nishat, M., \& Kemal, M. A. (2004). Volatility of exchange rate and export growth in Pakistan: The structure and interdependence in regional markets [with Comments]. The Pakistan Development Review, 813-828.

39. Abbas, S. K., Fazal, A., Ali, S. R., \& Faisal, N. (2019). Revaluation of Fixed Assets and Future Firm Performance: Evidence from Cement Sector of Pakistan. Journal of Computational and Theoretical Nanoscience, 16, 5-6, 2233-2236(4). https://www.ingentaconnect.com/contentone/asp/j ctn/2019/00000016/f0020005/art00080\#Refs

40. Yousafi, Q., ALI, H. A., Rashid, H., \& Khan, M. S. (2019). In silico comparative proteomic analysis of enzymes involved in fatty acid biosynthesis in castor bean (Ricinus communis) and soybean (Glycine max). Turkish Journal of Botany, 43(1), 1-26.

41. Goldstein, M., \& Khan, M. S. (1985). Income and price effects in foreign trade. Handbook of international economics, 2, 1041-1105.

42. Gigante, M. (2004). Vergil in the Shadow of Vesuvius. Vergil, Philodemus, and the Augustans, 85-99.

43. Chowdhury, A. (1993). Does exchange rate variability depress trade flows? Evidence from 
error correction models. Review of Economics and Statistics, 700-706.

44. Saad. (2015). Empircal Analyss of Aggregate Export Demand of Pakstan. Journal Glob Innov Agriculture Social Science, 9(9):30.

45. Bergstrand, J. H. (1989). The generalized gravity equation, monopolistic competition, and the factor-proportions theory in international trade. The review of economics and statistics, 143153.

46. Levinson, S. (2006). Cognition at the heart of human interaction. Discourse studies, 8(1), 85-93.

47. Bergstrand, J. H. (1985). The gravity equation in international trade: some microeconomic foundations and empirical evidence. The review of economics and statistics, 474-481.

48. Tinbergen, J. (1962). Shaping the World Economy (New York: The Twentieth Century Fund).

49. Poyhonen, P. (1963). A Tentative Model for the Volume of Trade between Countries. Weltwirtschaftliches Archiv.

50. Linnemann, H. (1966). An Econometric Study of International Trade Flows. North-Holland Publishing Co.

51. Anderson, M., \& Garcia, P. (1989). Exchange rate uncertainty and the demand for US soybeans. American Journal of Agricultural Economics, 71(3), 721-729.

52. Koo, W. W., Karemera, D., \& Taylor, R. (1994). A gravity model analysis of meat trade policies. Agricultural Economics, 10(1), 81-88.

53. Dell-Ariccia, G. (1999). Exchange rate fluctuations and trade flows: Evidence from the European Union. IMF Staff Papers, 46(3): 315334.

54. Tenreyro, S. (2004). On the Trade Impact of Nominal Exchange Rate Volatility, Federal Reserve Bank of Boston. Working Paper 03-2.

55. Bahmani-Oskooee, M., \& Payesteh, S. (1993). Does exchange rate volatility deter trade volume of LDCs?. Journal of Economic Development, 18(2), 189-205.

56. Arize, A. C., Malindretos, J., \& Kasibhatla, K. M. (2003). Does exchange-rate volatility depress export flows: The case of LDCs. International Advances in Economic Research, 9(1), 7-19.

57. Kemal, A. R., Qayyum, A., \& Hanif, M. N. (2004). Financial development and economic growth: evidence from a heterogeneous panel of high income countries.

58. Aqeel, A., \& Nishat, M. (2006). The Effect of Exchange Rate Volatility on Pakistan's Exports. Pakistan Economic and Social Review, 81-92.
59. Saha, M., Faroque, M. O., Alam, K. S., Alam, M. M., \& Ahmed, S. (2012). Chronic Kidney Disease specific cardiovascular risk factors among non dialytic patients with Chronic Kidney Disease stage-V An experience of a specialized hospital. Bangladesh Medical Research Council bulletin, 38(1), 18-22.

60. Krugman, P. R. O., \& Obstfeld, R. (2005). Maurice. Economía Internacional: Teoría y Política.

61. Shaheen, R., \& Nishat, M. (2005, June). Corporate governance and firm performance: An exploratory analysis. In Conference of Lahore School of Management Sciences, Lahore.

62. McIvor, J. G., Williams, J., \& Gardener, C. J. (1995). Pasture management influences runoff and soil movement in the semi-arid tropics. Australian Journal of Experimental Agriculture, 35(1), 55-65.

63. Engle, R. F. (1982). Autoregressive conditional heteroscedasticity with estimates of the variance of United Kingdom inflation. Econometrica: Journal of the Econometric Society, 987-1007.

64. Pozo, S. (1992). Conditional exchange-rate volatility and the volume of international trade: evidence from the early 1900s. The Review of Economics and Statistics, 325-329.

65. Bollerslev, T. (1986). Generalized autoregressive conditional heteroskedasticity. Journal of econometrics, 31(3), 307-327.

66. Juliano, R., Alam, M. R., Dixit, V., \& Kang, H. (2008). Mechanisms and strategies for effective delivery of antisense and siRNA oligonucleotides. Nucleic acids research,36(12), 4158-4171.

67. Cheng, I. H., \& Wall, H. J. (2005). Controlling for heterogeneity in gravity models of trade and integration. Federal Reserve Bank of St. Louis Review, 87(1): 49-63.

68. Krugman, P. (2005). For richer. Critical social issues in American education: Democracy and meaning in a globalizing world, 3 .

69. Gujarati, D. N. (2009). Basic econometrics. Tata McGraw-Hill Education.

70. Chowdhury, A. (1993). Does exchange rate variability depress trade flows? Evidence from error correction models. Review of Economics and Statistics.

71. Cheng, I. H., \& Wall, H. J. (1999). Controlling for heterogeneity in gravity models of trade. Federal Reserve Bank of St. Louis Working Paper, 99-110.

72. Kumar, V., \& Whitt Jr, J. A. (1992). Exchange rate variability and international trade. Economic Review-Federal Reserve Bank of Atlanta,77(3), 17-32. 